\title{
Synthesis of 2,3,5,6-tetrafluoro-pyridine derivatives from reaction of pentafluoropyridine with malononitrile, piperazine and tetrazole-5-thiol
}

\author{
Khalil Beyki, Reza Haydari and Malek Taher Maghsoodlou
}

\begin{abstract}
Some pentafluoropyridine derivatives have been synthesized by the reaction of pentafluoropyridine with appropriate $\mathrm{C}, \mathrm{S}$ and $\mathrm{N}$-nucleophile such as malononitrile, 1-methyl-tetrazole-5-thiol and piperazine. These reactions provided 4-substituted 2,3,5,6-tetrafluoropyridine derivatives in good yields. All the compounds were characterized using ${ }^{1} \mathrm{H}$, ${ }^{13} \mathrm{C}$ and ${ }^{19} \mathrm{~F}$-NMR spectroscopy and $\mathrm{X}$-ray crystallography.
\end{abstract}

Keywords: Pentafluoropyridine, Heterocycle, Nucleophilic Substitution, Synthesis, ${ }^{19} \mathrm{~F}-\mathrm{NMR}$

\section{Background}

Pentafluoropyridine and related compounds in which all the hydrogen atom in heterocyclic ring have been replaced by fluorine atoms were synthesized by reaction of potassium fluoride with perchloro heteroaromatic (Ojima 2009). In pharmacology, it is common to substitute hydrogen with fluorine atoms for increases the lipophilicity and biological activity of the compounds (Chambers et al. 2008a, b). Pentafluoropyridine one of the most important perfluoroheteroaromatic compounds have been used for the synthesis of various drug-like systems (Gutov et al. 2010). These systems are highly active towards nucleophilic additions owing to the presence of electronegative fluorine atoms and the presence of the nitrogen heteroatom so all five fluorine atoms in pentafluoropyridine may be substituted by an appropriate nucleophile (Cartwright et al. 2010; Chambers et al. 2005). A nucleophilic substitution reaction of pentafluoropyridine occurs in two-step addition-elimination mechanism, so install nucleophile addition and in the end elimination flour ring nitrogen (Colgin et al. 2012). The site reactivity order of pentafluoropyridine is well

\footnotetext{
*Correspondence: heydari@chem.usb.ac.ir

Department of Chemistry, Faculty of Science, University of Sistan and Baluchestan, P. O. Box 98135-674, Zahedan, Iran
}

known that, the order of activation toward nucleophilic attack follows these quence 4 (Para)-fluorine $>2$ (Ortho)fluorine $>3$ (Meta)-fluorine so the reactions of pentafluoropyridine with some nucleophilic occur selectively at the Para position as this site is most activated towards nucleophilic additions to afforded of 4-substited tetrafluoropyridine (Chambers et al. 2008a, b).

\section{Results and discussion}

In this research, we describe nucleophilic substitution of pentafluoropyridine with a wide range of nucleophiles and highlight how the resulting products 4 -substited2,3,5,6-tetrafluoro-pyridine derivatives. Reaction of pentafluoropyridine $\mathbf{1}$ with malononitrile $\mathbf{2 a}$ under basic conditions $\left(\mathrm{K}_{2} \mathrm{CO}_{3}\right)$ in DMF at reflux gave a 4-(malononitrile)-2,3,5,6-tetrafluoropyridine 6a (Fig. 1).

In basic condition, malononitrile 2a deprotonate and carbon nucleophile of malononitrile attack to Para position of pentafluoropyridine $\mathbf{1}$ and elimination of 4-fluor ring pyridine to give $\mathbf{5 a}$. In $\mathbf{5 a}$, hydrogen malononitrile very acidy so essay deprotonate in base solution to give potassium dicyano (perfluoropyridin-4-yl) methanide 6a (Fig. 2). Purification of 6a was achieved by recrystallization in ethanol/acetonitrile. In crystal $\mathbf{6 a}$, two molecule chelate by potassium ion between flour and nitrogen. Identification of chelate $\mathbf{6 a}$ was done by 


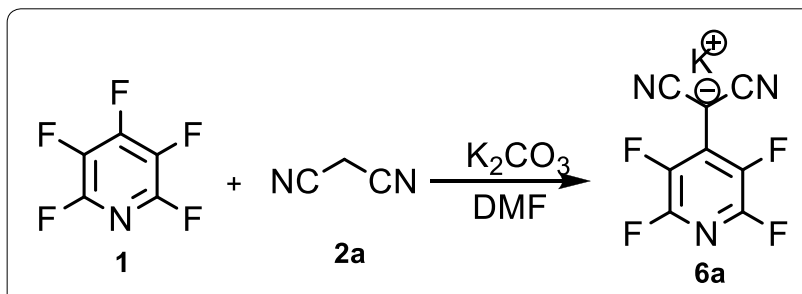

Fig. 1 Reaction of pentafluoropyridine with malononitrile

${ }^{19} \mathrm{~F}$-NMR analysis, in which the resonance attributed to fluorines located Ortho to ring nitrogen has a chemical shift of $-83.5 \mathrm{ppm}$ and $-84.4 \mathrm{ppm}$. The corresponding resonance for fluorines located Meta to ring nitrogen in chelate $\mathbf{6 a}$ occurred at -135.4 and $-139.4 \mathrm{ppm}$. Four resonances by ${ }^{19} \mathrm{~F}$-NMR indicate displacement of fluorine atoms attached to the Para position of two pyridine ring. The ${ }^{1} \mathrm{H}-\mathrm{NMR}$ spectra of compound $\mathbf{6 a}$ consisted of a $\mathrm{H}$ broad signal at $\delta=7.29 \mathrm{ppm}$ for $\mathrm{CH}$ malononitrile. X-ray crystallography confirmed the structure of chelate $\mathbf{6 a}$ (Figs. 3, 4). A summary of the crystal data, experimental details and refinement results for $\mathbf{6 a}$ is given in Table 1.
Reaction of 1-methyl-tetrazole-5-thiol $2 \mathbf{b}$ with pentafluoropyridine $\mathbf{1}$ in acetonitrile at reflux temperature and recrystallisation in ethanol gave 2-ethoxy-3,5,6-trifluoro-4-((1-methyl-1H-tetrazol-5-yl)thio)pyridine $\mathbf{5 b}$ (Fig. 5). In 1-methyl-1H-tetrazole-5-thiol, sulfur atom more nucleophilic than other atoms, so install attack at the Para position of the pyridine ring to give $\mathbf{4 b}$. Purification of $\mathbf{4 b}$ was achieved by recrystallization in ethanol (accessible and non-toxic solvent). In hot EtOH, Ethoxy group attack at ortho position of 2,3,5,6-tetrafluoro-4(1-methyl-1H-tetrazol-5-ylthio)pyridine $\mathbf{4 b}$ to give $\mathbf{5 b}$ (Fig. 6). Identification of $\mathbf{5 b}$ was done from ${ }^{19} \mathrm{~F}-\mathrm{NMR}$ analysis in which the resonance attributed to displacement of fluorine atoms attached only at the Para and Ortho position of the pyridine ring. The corresponding resonance for F-3,5 (Meta) in $\mathbf{5 b}$ occurs at -131 and $-154 \mathrm{ppm}$ and F-6 (ortho) at $-88 \mathrm{ppm}$. Other spectroscopic techniques were consistent with the structures proposed. The protons of the methyl group, were observed at $\delta=4.13 \mathrm{ppm}$. The molecular structure of the 2-ethoxy-3,5,6-trifluoro-4-((1-methyl-1H-tetrazol-5-yl) thio) pyridine obtained has been determined by X-ray

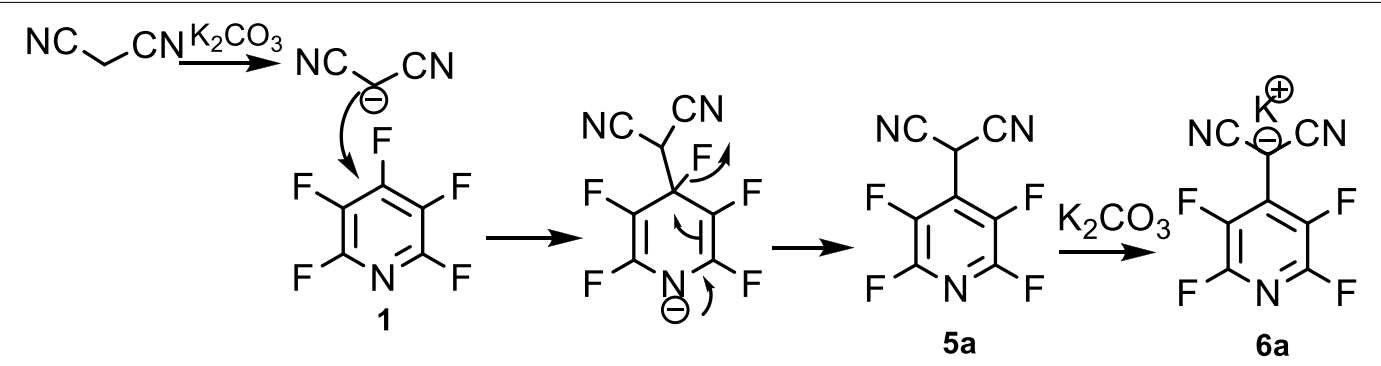

Fig. 2 The suggested mechanism nucleophilic substitution of pentafluoropyridine with malononitrile

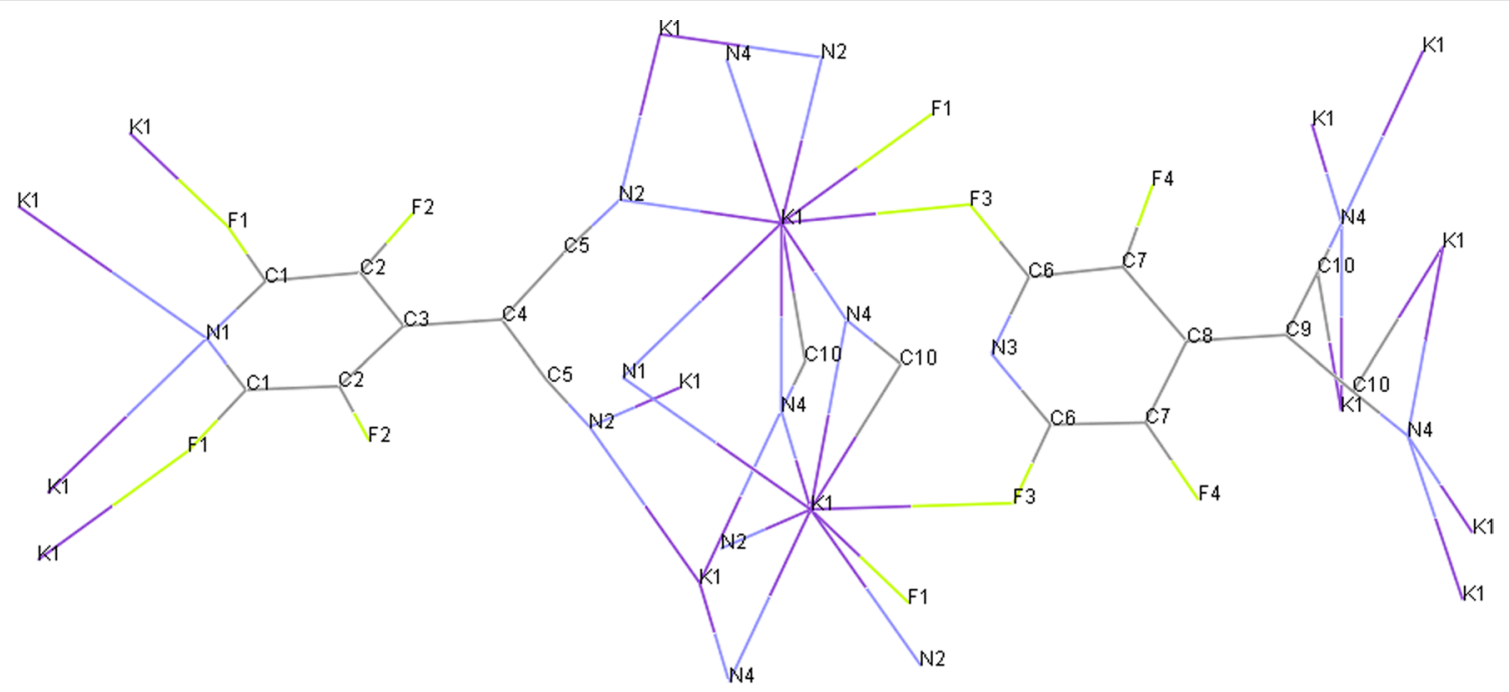

Fig. 3 X-ray structure of $\mathbf{6 a}$ 


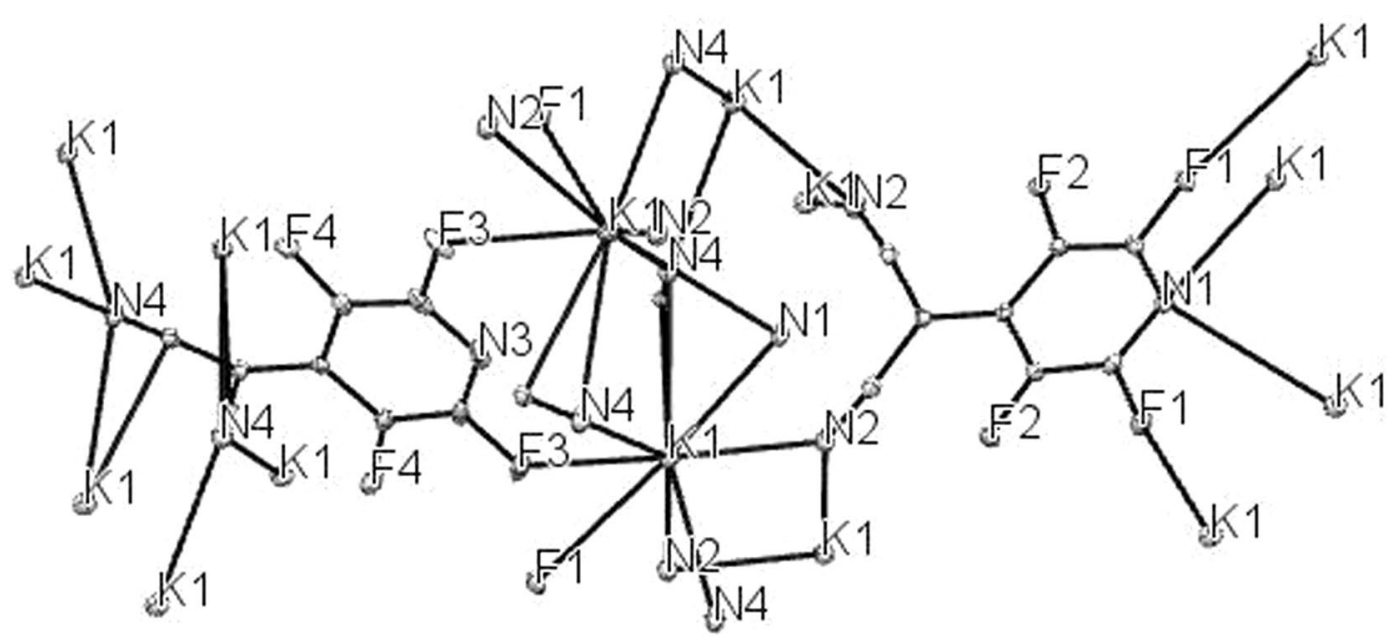

Fig. 4 ORTEP diagram of $\mathbf{6 a}$

Table 1 Crystal data for $6 a, 5 b$ and $3 c$

\begin{tabular}{|c|c|c|c|}
\hline Compound & $6 a$ & $5 \mathbf{b}$ & $3 c$ \\
\hline Formula & $\mathrm{C}_{8} \mathrm{~F}_{4} \mathrm{KN}_{3}$ & $\mathrm{C}_{9} \mathrm{H}_{8} \mathrm{~F}_{3} \mathrm{~N}_{5} \mathrm{OS}$ & $\mathrm{C}_{14} \mathrm{H}_{8} \mathrm{~F}_{8} \mathrm{~N}_{4}$ \\
\hline Formula weight & 253.21 & 291.26 & 384.24 \\
\hline Wavelength & 0.71073 & 0.71073 & 0.71073 \\
\hline Crystal system & Monoclinic & Monoclinic & Orthorhombic \\
\hline Space group & $\mathrm{C} 2 / \mathrm{c}$ & $P 21 / n$ & $P b c a$ \\
\hline Unit cell dimensions $(\AA \AA)$ & $\begin{array}{l}a=11.882(2) \\
b=18.857(4) \\
c=7.7561(15) \\
a=90 \\
\beta=108.369(3) \\
\gamma=90\end{array}$ & $\begin{array}{l}a=9.0254(9) \\
b=7.5269(8) \\
c=17.9941(19) \\
a=90 \\
\beta=99.1260(10) \\
\gamma=90\end{array}$ & $\begin{array}{l}a=8.8425(5) \\
b=11.0779(4) \\
c=14.5459(7) \\
a=90 \\
\beta=90 \\
\gamma=90\end{array}$ \\
\hline Volume $\AA^{3}$ & $1649.2(6)$ & $1206.9(2)$ & $1424.86(12)$ \\
\hline Z & 8 & 4 & 4 \\
\hline Density (calculated) $\mathrm{g} \mathrm{cm}^{-1}$ & 2.040 & 1.603 & 1.791 \\
\hline$F(000)$ & 992 & 592 & 768 \\
\hline Crystal size & $0.469 \times 0.196 \times 0.165$ & $0.309 \times 0.240 \times 0.151$ & - \\
\hline$\Theta$ range for data & $2.99^{\circ}-32.57^{\circ}$ & $0.999^{\circ}-1.000^{\circ}$ & $3.264^{\circ}-28.311^{\circ}$ \\
\hline Index range & $\begin{array}{l}-17<h<17 \\
-28<k<28 \\
-11<l<11\end{array}$ & $\begin{array}{l}-12<h<12 \\
-10<k<10 \\
-25<l<25\end{array}$ & $\begin{array}{l}-11<h<11 \\
-14<k<13 \\
-19<\mid<18\end{array}$ \\
\hline Absorption coefficient $\mathrm{mm}^{-1}$ & 0.682 & 0.307 & 0.184 \\
\hline Parameters/restraints & $148 / 0$ & 0 & 0 \\
\hline Final $R_{1}^{a} \cdot w R_{2}^{b}$ (Obs. data) & $0.0249,0.0781$ & $0.0503,0.0411$ & $0.0500,0.1435$ \\
\hline Final $R_{1}^{a}, w R_{2}^{b}$ (all data) & $0.0277,0.0781$ & $0.1207,0.1122$ & $0.0690,0.1681$ \\
\hline Goodness of fit on $F^{2}(S)$ & 1.468 & 1.035 & 1.295 \\
\hline
\end{tabular}

crystallography (Figs. 7, 8). A summary of the crystal data, experimental details and refinement results for $\mathbf{5 b}$ is given in Table 1.

Also, we examined the reaction of pentafluoropyridine $\mathbf{1}$ with piperazine $\mathbf{2 c}$ in the presence of sodium carbonate in $\mathrm{CH}_{3} \mathrm{CN}$ solvent gave 1,4-bis(perfluoropyridin-4-yl)piperazine 3c (Fig. 9). In basic condition, two nitrogen of the piperazine deprotonation and attack to Para position of pentafluoropyridine and elimination of 4-fluor pyridine ring to give $3 \mathrm{e}$ 


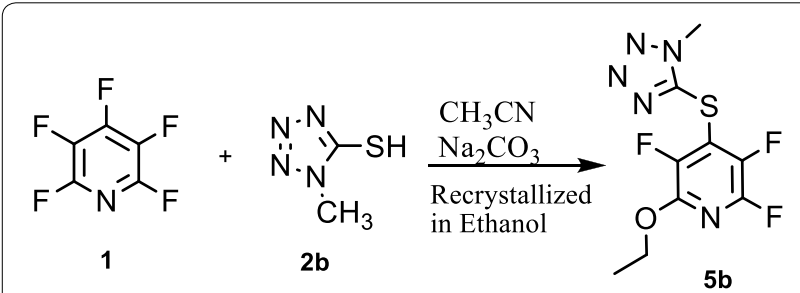

Fig. 5 Reaction of pentafluoropyridine with 1-methyl-tetrazole5-thiol

(Fig. 10). Purification of $\mathbf{3 c}$ was achieved by recrystallization in acetonitrile. The structure of compounds $3 \mathbf{c}$ was confirmed by X-ray crystallography and by NMR spectroscopic data. In particular, ${ }^{19} \mathrm{~F}$-NMR spectroscopy shows the chemical shift of fluorine atoms attached to the Ortho and Meta position are observed respectively at -97.3 and $-160.5 \mathrm{ppm}$. In ${ }^{1} \mathrm{H}-\mathrm{NMR}$, the protons of $\mathrm{CH}_{2}$ piperazine, was observed at $\delta=4.3 \mathrm{ppm}$. The ${ }^{13} \mathrm{C}$ NMR spectrum of compound 3c showed 4 distinct resonances in agreement with the proposed structure. The structure of 3c was confirmed by X-ray crystallography (Figs. 11, 12).

\section{Conclusion}

In conclusion, we showed that pentafluoropyridine can successfully react with a variety of nucleophiles to afford of 4-substited tetrafluoropyridine. The regioselectivity of nucleophilic substitution in this process may be explained by high nucleophilicity of sulfur, nitrogen or oxygen and activating influence of pyridine ring nitrogen that significantly activate the Para and Ortho sites to itself.

\section{Experimental}

All materials and solvents were purchased from Merck and Aldrich and were used without any additional purification. The melting points of the products were determined in open capillary tubes using BAMSTEAB Electrothermal apparatus model 9002. The $1 \mathrm{H}$ NMR spectra were recorded at $300 \mathrm{MHz}$. The ${ }^{13} \mathrm{C}-\mathrm{NMR}$

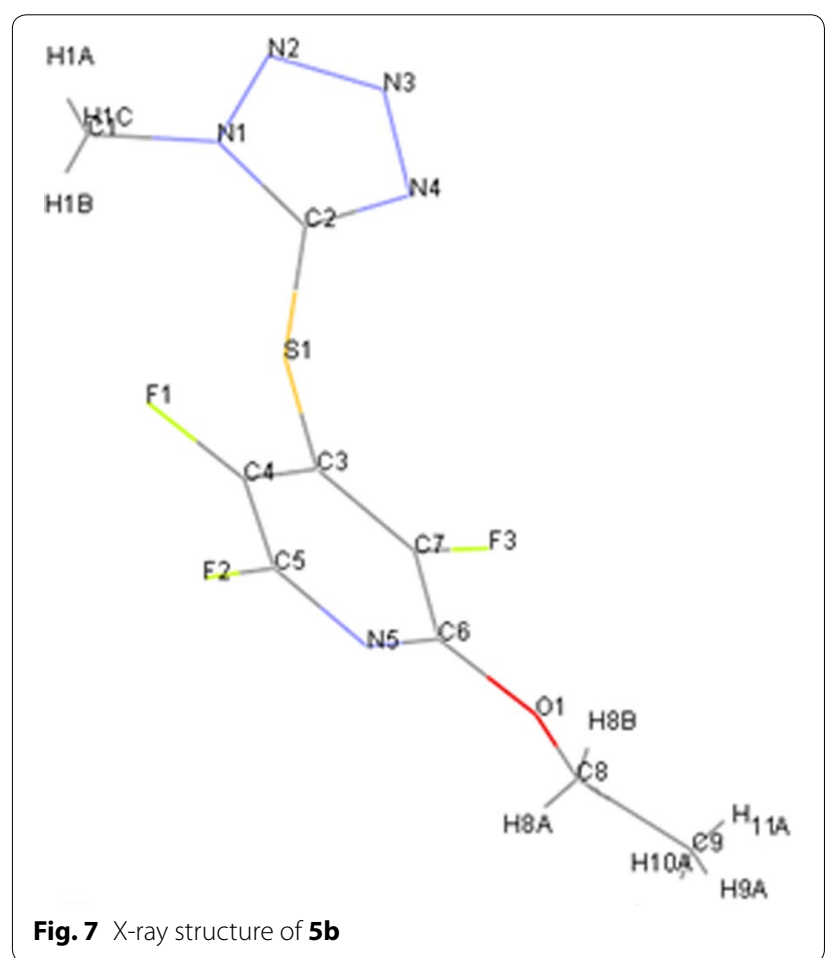

spectra were recorded at $75 \mathrm{MHz}$. The ${ }^{19} \mathrm{~F}$-NMR spectra were recorded at $282 \mathrm{MHz}$. In the ${ }^{19} \mathrm{~F}-\mathrm{NMR}$ spectra, up field shifts were quoted as negative and referenced to $\mathrm{CFCl}_{3}$. Mass spectra were taken by a Micro mass Platform II: EI mode $(70 \mathrm{eV})$. Silica plates (Merck) were used for TLC analysis.

\section{Preparation of 2-(perfluoropyridin-4-yl)malononitrile 6a}

Pentafluoropyridine $1(0.1 \mathrm{~g}, 0.6 \mathrm{mmol})$, malononitrile 2a $(0.04 \mathrm{~g}, 0.6 \mathrm{mmol})$ and potassium carbonate $(0.11 \mathrm{~g}$, $1.0 \mathrm{mmol}$ ) were stirred together in DMF $(5 \mathrm{~mL})$ at reflux temperature for $3 \mathrm{~h}$. The reaction mixture was evaporated to dryness than the solid product was recrystallisation from acetonitrile to give 2-(perfluoropyridin-4-yl) malononitrile $(0.22 \mathrm{~g}, 86 \%)$ as a red crystals; $\mathrm{mp} 260{ }^{\circ} \mathrm{C}$ dec, ${ }^{19} \mathrm{~F}$ NMR (acetone): ${ }^{1} \mathrm{H}$ NMR (acetone): $\delta$ (ppm) 7.79

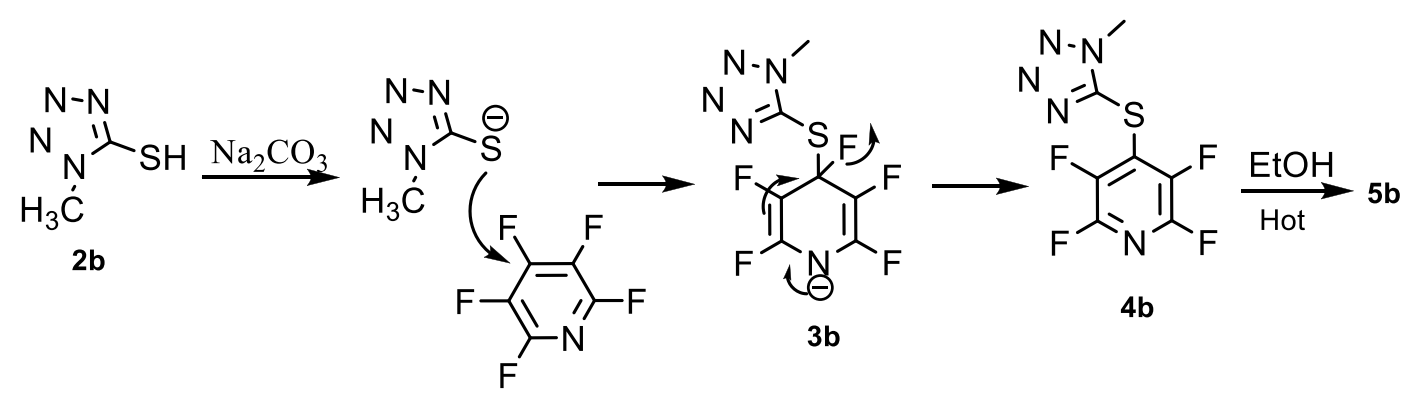

Fig. 6 The suggested mechanism nucleophilic substitution of pentafluoropyridine with 1-methyl-1H-tetrazole-5-thiol 


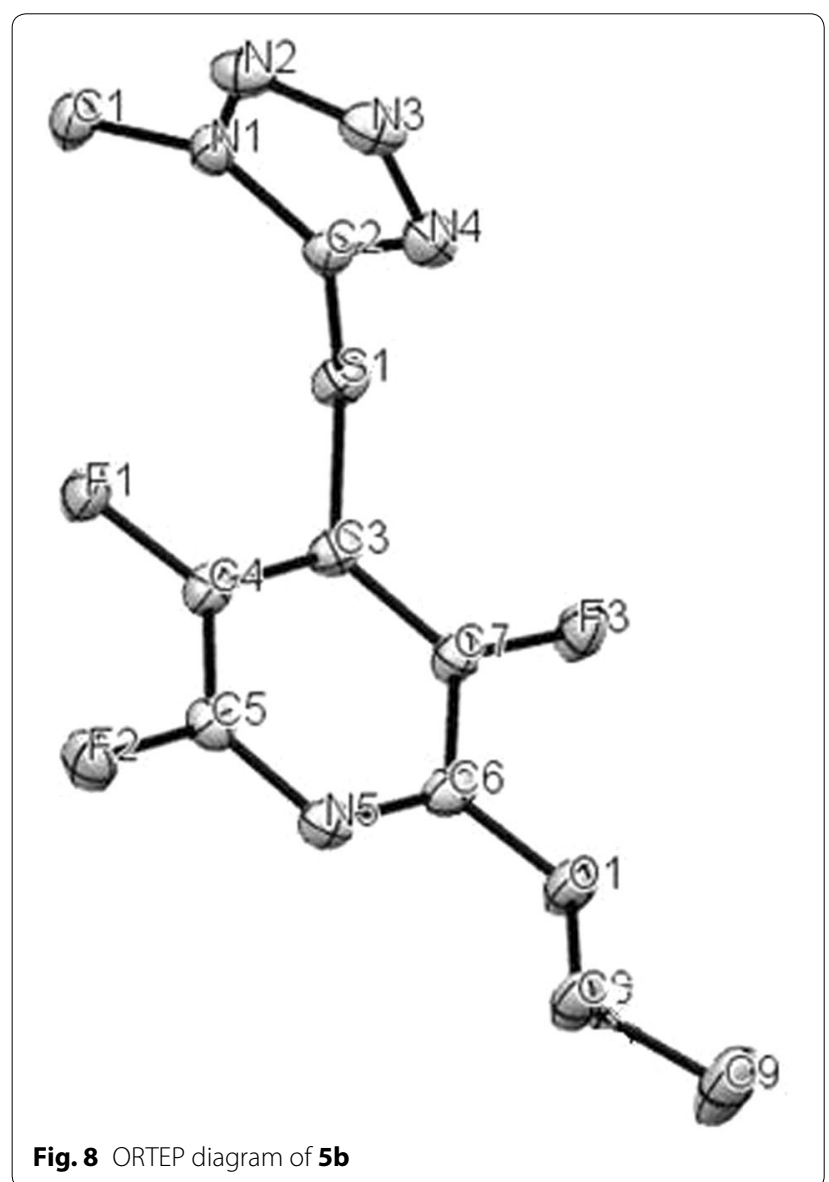

Fig. 8 ORTEP diagram of $\mathbf{5 b}$

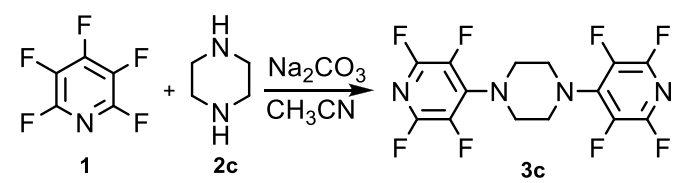

Fig. 9 Reaction of pentafluoropyridine with piperazine

(s, 1H, CH); $\delta(\mathrm{ppm})-83.5(\mathrm{~m}, 2 \mathrm{~F}, \mathrm{~F}-2,6),-84.4(\mathrm{~m}, 2 \mathrm{~F}$, $\left.\mathrm{F}-2^{\prime}, 6^{\prime}\right),-135.4(\mathrm{~m}, 2 \mathrm{~F}, \mathrm{~F}-3,5),-139.4\left(\mathrm{~m}, 2 \mathrm{~F}, \mathrm{~F}-3^{\prime}, 5^{\prime}\right)$. MS $(\mathrm{EI}), \mathrm{m} / \mathrm{z}(\%)=508\left(\mathrm{M}^{+}\right), 440,364,291,180,147,121$, $105,91,77,57,43$.

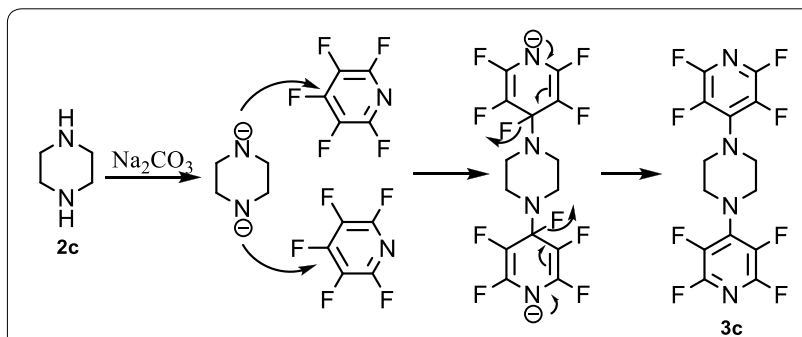

Fig. 10 The suggested mechanism nucleophilic substitution of piperazine with pentafluoropyridine

\section{Preparation}

of 2-ethoxy-3,5,6-trifluoro-4-((1-methyl-1H-tetrazol-5-yl) thio)pyridine $\mathbf{5 b}$

Pentafluoropyridine $\mathbf{1}$ (0.1 g, $0.6 \mathrm{mmol})$, 1-methyl-1Htetrazole-5-thiol $\mathbf{2 b}(0.09 \mathrm{~g}, 0.6 \mathrm{mmol})$ and sodium hydrogencarbonate $(0.11 \mathrm{~g}, 1.0 \mathrm{mmol})$ were stirred together in $\mathrm{CH}_{3} \mathrm{CN}(5 \mathrm{~mL})$ at reflux temperature for $4 \mathrm{~h}$ (monitored by TLC). The solvent was evaporated; water $(5 \mathrm{~mL})$ was added and extracted with dichloromethane and ethyl acetate $(3 \times 5 \mathrm{~mL})$. Solvent evaporation and recrystallisation from ethanol gave 2-ethoxy-3,5,6-trifluoro-4-((1methyl-1H-tetrazol-5-yl)thio)pyridine $5 \mathbf{b}$ (0.2 g, 75 \%) as a white crystal; mp $130{ }^{\circ} \mathrm{C}$ dec. ${ }^{1} \mathrm{H}$ NMR (acetone): $\delta$ (ppm) $1.37\left(3 \mathrm{H}, \mathrm{m}, \mathrm{CH}_{3}\right), 3.90\left(3 \mathrm{H}, \mathrm{s}, \mathrm{N}-\mathrm{CH}_{3}\right), 4.3(2 \mathrm{H}$, $\left.\mathrm{m}, \mathrm{CH}_{2}\right) ;{ }^{19} \mathrm{~F}$ NMR (acetone): $\delta$ (ppm) -88.6 (1F, m, F-2), -131.4 (1F, m, F-3), -154.8 (1F, m, F-5); ${ }^{13} \mathrm{C}$ NMR (acetone): $\delta$ (ppm) 14.6, 35.5, 63.2, 64.4, 139.2, 140.5, 142.6, 143.7, $145.9 \mathrm{ppm}$. MS (EI), m/z $(\%)=292\left(\mathrm{M}^{+}\right), 263,235$, $219,180,132,100,83,43$.

\section{Preparation of 1,4-bis(perfluoropyridin-4-yl)piperazine 3c} Pentafluoropyridine $\mathbf{1}(0.1 \mathrm{~g}, 0.6 \mathrm{mmol})$, piperazine 2c $(0.03 \mathrm{~g}, 0.5 \mathrm{mmol})$ and sodium hydrogencarbonate $(0.11 \mathrm{~g}, 1.0 \mathrm{mmol})$ were stirred together in $\mathrm{CH}_{3} \mathrm{CN}$ $(5 \mathrm{~mL})$ at reflux temperature for $5 \mathrm{~h}$. After complicated reaction, the solvent was evaporated; water $(5 \mathrm{~mL})$ was added and extracted with dichloromethane and ethyl acetate $(3 \times 5 \mathrm{~mL})$. Solvent evaporation and recrystallization from $\mathrm{CH}_{3} \mathrm{CN}$ gave 1,4-bis(perfluoropyridin-4-yl) piperazine 3c $(0.2 \mathrm{~g}, 52 \%)$ as a white crystal; mp $288{ }^{\circ} \mathrm{C}$ dec. ${ }^{1} \mathrm{H}$ NMR (acetone): $\delta(\mathrm{ppm}) 4.30\left(8 \mathrm{H}, \mathrm{s}, \mathrm{CH}_{2}\right) ;{ }^{19} \mathrm{~F}$ NMR (acetone): $\delta$ (ppm) -97.3 (4F, m, F-2,6), -160.5 (4F, 


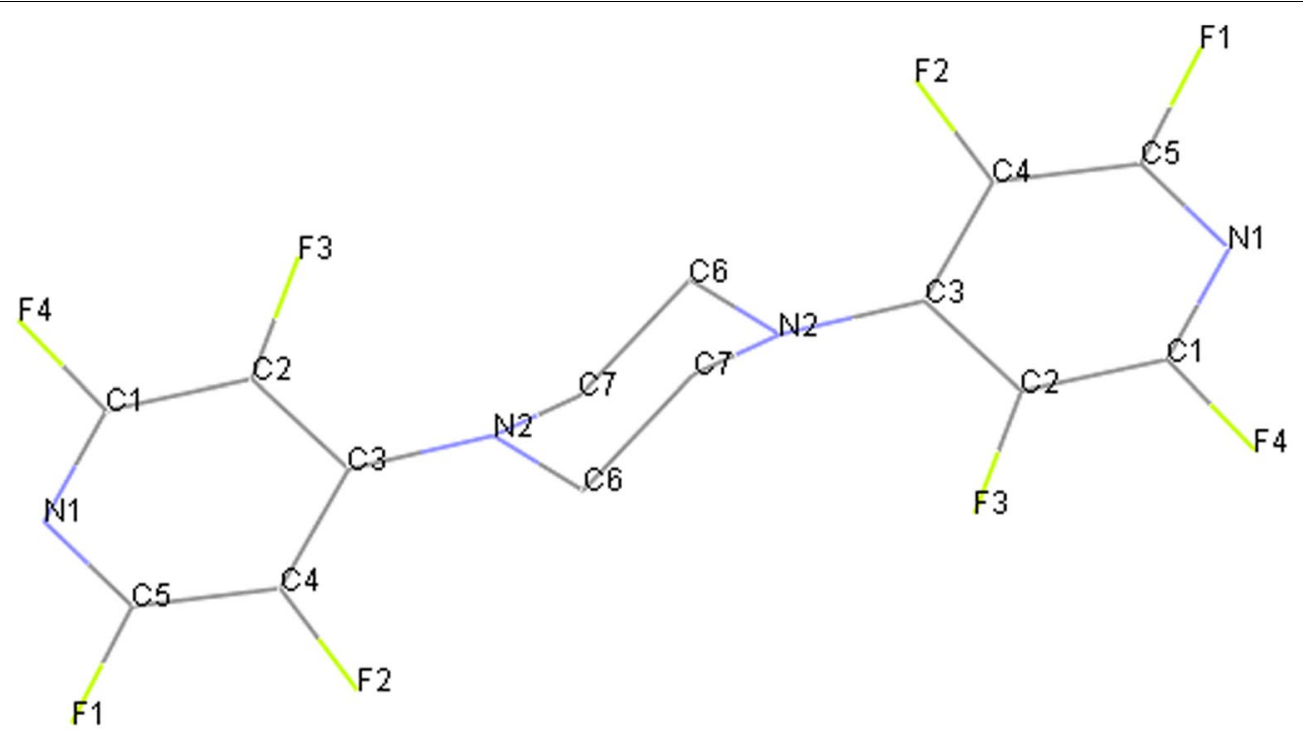

Fig. 11 X-ray structure of $\mathbf{3 c}$

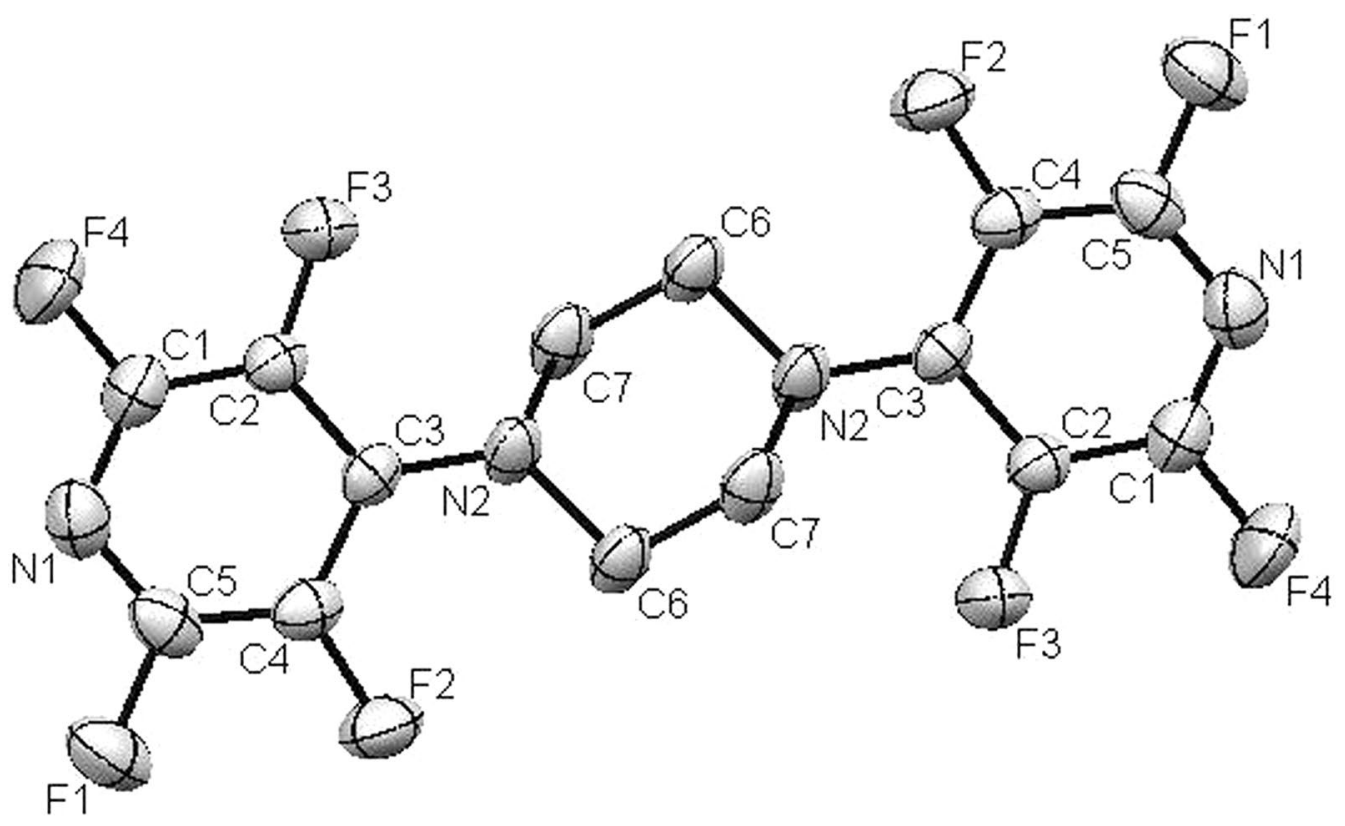

Fig. 12 ORTEP diagram of $\mathbf{3 c}$

m, F-3,5). ${ }^{13} \mathrm{C}-\mathrm{NMR}$ (acetone): $\delta$ (ppm) 60.3, 123.7, 127.1, $131.3 \mathrm{ppm}$. MS (EI), $\mathrm{m} / \mathrm{z}(\%)=384\left(\mathrm{M}^{+}\right), 317,292,263$, $235,219,180,152,132,116,100,83,63,43$.

\section{Authors' contributions}

$\mathrm{KB}, \mathrm{RH}$ and MTM were involved in the study design and manuscript preparation, data collection, data analysis and revisions. All authors read and approved the final manuscript.

\section{Acknowledgements}

The authors wish to thank Evan Sarina from University of California for the partial support of this work.

\section{Competing interests}

None declared under financial, general, and institutional competing interests. I wish to disclose a competing interest(s) such as those defined above or others that may be perceived to influence the results and discussion reported in this paper. 
Received: 8 September 2015 Accepted: 2 November 2015

Published online: 04 December 2015

\section{References}

Cartwright MW, Parks EL, Pattison G, Slater R, Sandford G, Wilson I, Yufit DS, Howard JAK, Christopher JA, Miller DD (2010) Tetrahedron 66:3222-3227

Chambers RD, Khalil A, Murray CB, Sandford G, Batsanov AS, Howard JAK (2005) J Fluor Chem 126:1002-1008

Chambers RD, Martin PA, Sandford G, Williams DLH (2008a) J Fluor Chem 129:998-1002
Chambers RD, Martin PA, Sandford G, Williams DLH (2008b) J Fluor Chem 129:998-1004

Colgin N, Tatum NJ, Pohl E, Cobb S, Sandford G (2012) J Fluor Chem 133:33-37 Gutov AV, Rusanov EB, Ryabitskii AB, Chernega AN (2010) J Fluor Chem 131:278-281

Ojima I (2009) Fluorine in medicinal chemistry and chemical biology. Blackwell, London

\section{Submit your manuscript to a SpringerOpen ${ }^{\odot}$} journal and benefit from:

- Convenient online submission

- Rigorous peer review

- Immediate publication on acceptance

- Open access: articles freely available online

- High visibility within the field

- Retaining the copyright to your article

Submit your next manuscript at $>$ springeropen.com 